\title{
Influence of soil properties on the bioaccumulation and effects of arsenic in the earthworm Eisenia andrei
}

\author{
A. Romero-Freire ${ }^{1,3}$ • F. J. Martín Peinado ${ }^{1}$ - M. Díez Ortiz ${ }^{2}$. \\ C. A. M. van Gestel ${ }^{3}$
}

Received: 27 January 2015 / Accepted: 4 May 2015 /Published online: 24 May 2015

(C) The Author(s) 2015. This article is published with open access at Springerlink.com

\begin{abstract}
This study aimed at assessing the influence of soil properties on the uptake and toxicity effects of arsenic in the earthworm Eisenia andrei exposed for 4 weeks to seven natural soils spiked with different arsenic concentrations. Watersoluble soil concentrations (AsW) and internal As concentrations in the earthworms (AsE) were greatly different between soils. These two variables were highly correlated and were key factors in earthworm toxicity response. AsW was explained by some soil properties, such as the $\mathrm{pH}$, calcium carbonate content, ionic strength, texture or oxide forms. Toxicity showed a clear variation between soils, in some cases without achieving $50 \%$ adverse effect at the highest As concentration added $\left(600 \mathrm{mg} \mathrm{kg}^{-1}\right)$. Nevertheless, soil properties did not
\end{abstract}

Responsible editor: Philippe Garrigues

Highlights - Arsenic toxicity to earthworm Eisenia andrei was assessed in different soils.

- As solubility was controlled by oxides, organic carbon content, $\mathrm{pH}$ and ionic strength.

- Toxicity was explained by total and available As concentrations and soil properties.

- Main soil properties influencing toxicity were ionic strength, phosphorous and base saturation.

- Differences in soil properties caused large differences in As toxicity.

A. Romero-Freire

anaromerof@ugr.es

1 Department of Soil Science, University of Granada, Avd. Fuente Nueva, 18002 Granada, Spain

2 NanoHealth \& Safety group, R\&D department of LEITAT Technological Centre, Carrer de la Innovació, 2, 08225 Terrasa, Barcelona, Spain

3 Department of Ecological Science, Faculty of Earth and Life Sciences, VU University, De Boelelaan 1085, 1081 HV Amsterdam, The Netherlands show, in general, a high relation with studied toxicity endpoints, although the high correlation with AsW could greatly reduce indirectly As bioavailability and toxicity risk for earthworms. Obtained results suggest that soil properties should be part of the criteria to establishing thresholds for contaminated soils because they will be key in controlling As availability and thus result in different degrees of toxicity.

Keywords Arsenic · Bioavailability $\cdot$ Soil properties . Earthworm accumulation $\cdot$ Toxicity

\section{Introduction}

Arsenic is a metalloid which is found at widely varying concentrations in different environments (Kabata-Pendias and Pendias 2001). Currently, its presence is associated with natural and anthropogenic sources, and in many areas, its environmental levels in water, sediments or soils are of major concern due to its potential adverse health effects (Nriagu et al. 2007).

To determine the reference levels of metals in soils, it is necessary to know their contents under natural conditions (soil background) (Martín et al. 2012). Arsenic background concentration in soil is highly variable as it depends on the initial concentration in the parent material, natural geochemical cycles and soil type (Díez et al. 2007). The bioavailability and therefore the toxicity of metals to organisms in terrestrial ecosystems are largely controlled by soil properties (Sheppard and Evenden 1988). The solubility of arsenic and therefore also its toxicity are known to be strongly controlled by soil properties and constituents (Martín Peinado et al. 2012). The most important variables affecting As availability in soils seem to be the organic carbon content, $\mathrm{pH}$, ionic strength of the soil solution, iron oxides and cation exchange capacity (Romero-Freire et al. 2014; Song et al. 2006). 
Evaluation of the effects of contaminants in soils has become a priority for OECD member countries (Saint-Denis et al. 2001; Arnaud et al. 2000). Most environmental protection policies are based on guidance based on total concentrations of a particular element or compound in soil, referring to land-use type but not to the soil type. This creates a large variety of soil quality criteria for metals in different countries. For example, the intervention levels for As in agricultural soils in Europe range from $10 \mathrm{mg} \mathrm{As} \mathrm{kg}^{-1}$ soil in the UK (Barth and L'hermite 1987) to $50 \mathrm{mg} \mathrm{As} \mathrm{kg}{ }^{-1}$ soil in the Netherlands (NMHPPE 1994).

The accumulation of trace elements from soil to biota has been studied extensively for many species (Díez-Ortiz et al. 2010; Nahmani et al. 2007). Earthworms are more susceptible to metal pollution than many other soil invertebrates (Spurgeon and Hopkin 1996; Bengtsson et al. 1992). Furthermore, earthworms have a number of characteristics (large size, behaviour and high biomass) which make them highly suitable animals for use as bioindicator organisms for determining the toxicity of chemicals in soils (Arnaud et al. 2000; Callahan 1988; Goats and Edwards 1988; Bouché 1992). Consequently, they have been adopted as standard organisms for ecotoxicological testing by the European Union (EEC 1984), with Eisenia andrei commonly used as the test species not only in standardized toxicity tests (OECD 1984) but also in bioassays to assess the toxicity of fieldcontaminated soils (Fleuren et al. 2003; Cortet et al. 1999).

To determine toxicity guidance values, usually artificially contaminated soils are used, which may differ in composition from in situ contaminated soil. As a consequence, laboratory experiments tend to overestimate the solubility and availability of metals compared to field-contaminated soils (Smolders et al. 2009; van Gestel et al. 2012). The toxicity level defined by laboratory studies commonly overestimates the effects, which can lead to high strict safety thresholds for the environmental risk assessment (Romero-Freire et al. 2014).

The aim of this study was to determine the effect of soil properties on the bioavailability of arsenic by measuring its uptake and toxicity using the earthworm Eisenia andrei. The earthworms were exposed to a wide range of soils with contrasting properties spiked with different arsenic concentrations. This study is part of a broader project that involves assessing the toxicity of arsenic to different organisms for the purpose of establishing guideline values to improve the existing regulation regarding soil pollution in Spain (RomeroFreire et al. 2014).

\section{Materials and methods}

\section{Soils}

Seven soils with different properties, representing most of the main soil groups in Spain, were selected (Table 1). The main parameters analysed were $\mathrm{pH}$ (soil to water or soil to $0.1 \mathrm{M}$ $\mathrm{KCl}$ in a ratio $1: 2.5$ ), ionic strength of the soil (I) derived from the electric conductivity according to Simón and García (1999), calcium carbonate content $\left(\mathrm{CaCO}_{3}\right)$, organic carbon content (OC), available phosphorous content $(\mathrm{P})$, water holding capacity (WHC), available water (AW) calculated from differences in moisture contents at the field capacity (h33) and the wilting point (h1500), texture, cation exchange capacity (CEC). These properties were determined according to official methods of analysis (M.A.P.A. 1994). Moreover, concentrations of free and amorphous iron, aluminium and manganese oxides were analysed according to Holmgren (1967) and Schwertmann and Taylor (1977), respectively.

Soils were contaminated in the laboratory with increasing concentrations of sodium arsenate $\left(\mathrm{Na}_{2} \mathrm{HAsO}_{4} \cdot 7 \mathrm{H}_{2} \mathrm{O}\right)$ according to the reference values proposed by the Junta de Andalusia (Aguilar et al. 1999) for agricultural, natural and industrial use (50-100-300 $\mathrm{mg} \mathrm{As} \mathrm{kg}^{-1}$, respectively) and adding one more level to create a worst case scenario (600 mg As kg-1). Furthermore, an uncontaminated level (control) was included. Contamination was performed by spiking samples of $500 \mathrm{~g}$ of soil (dry weight) with aqueous As solutions $(n=3)$. After spiking, the soils were moistened to $60 \%$ of their WHC and incubated for 4 weeks at $25 \pm 1{ }^{\circ} \mathrm{C}$ and $60 \%$ air humidity, with a light to dark cycle of 10:14 h. Soil moisture content was checked and, if needed, readjusted weekly. The incubation period chosen allows stabilization of the arsenic added and was based on similar studies by other authors (Romero-Freire et al. 2014; Tang et al. 2006; Fendorf et al. 2004). After the incubation period, a saturated extract was prepared with a soil to water ratio of $1: 1$ and was stirred for $24 \mathrm{~h}$; then, a soil solution was obtained by extraction with a 10-cm Rhizon MOM and analysed for $\mathrm{pH}$, electrical conductivity, and water-soluble As concentrations (Romero-Freire et al. 2014).

\section{Earthworm toxicity testing}

Earthworms of the species $E$. andrei were supplied by Lombricor SCA (Córdoba, Spain). Earthworms were cultured at $20^{\circ} \mathrm{C}$ in a substrate of soil with high organic matter content, peat and abundant horse manure free of any pharmaceutical. Before the start of the exposures, adult worms with welldeveloped clitella were selected with an average weight of $0.50 \pm 0.08 \mathrm{~g}$.

The earthworm toxicity tests followed OECD guideline 222 (OECD 2004), including a 4-week exposure period of adult animals. Three replicate test containers were used for each arsenic concentration and control, containing approximately $500 \mathrm{~g}$ soil (dry weight equivalent). Ten adult earthworms were added to each test container after being gently cleaned on moistened paper towels and weighed. To feed the worms, $25 \mathrm{~g}$ of horse manure:distilled water (1:4 ratio) was 
Table 1 Main properties of the soils used to assess the influence of soil properties on the uptake and effects of As in earthworms

\begin{tabular}{llllllllllllllllllll}
\hline Soil & $\begin{array}{l}\mathrm{As}^{\mathrm{a}} \\
\left(\mathrm{mg} \mathrm{kg}^{-1}\right)\end{array}$ & $\begin{array}{l}\mathrm{pHH} \mathrm{O} \\
(1: 2.5)\end{array}$ & $\begin{array}{l}\mathrm{pHKCl} \\
(1: 2.5)\end{array}$ & $\begin{array}{l}\mathrm{I} \\
\left(\mathrm{mmol} \mathrm{L}^{-1}\right)\end{array}$ & $\begin{array}{l}\mathrm{P} \\
\left(\mathrm{mg} \mathrm{kg}^{-1}\right)\end{array}$ & $\begin{array}{l}\mathrm{CaCO}_{3} \\
(\%)\end{array}$ & $\begin{array}{l}\mathrm{OC} \\
(\%)\end{array}$ & $\begin{array}{l}\mathrm{Clay} \\
(\%)\end{array}$ & $\begin{array}{l}\mathrm{Silt} \\
(\%)\end{array}$ & $\begin{array}{l}\mathrm{CEC} \\
\left(\mathrm{cmol}^{+} \mathrm{kg}^{-1}\right)\end{array}$ & $\begin{array}{l}\mathrm{Al}_{\mathrm{d}} \\
(\%)\end{array}$ & $\begin{array}{l}\mathrm{Al}_{\mathrm{o}} \\
(\%)\end{array}$ & $\begin{array}{l}\mathrm{Fe}_{\mathrm{d}} \\
(\%)\end{array}$ & $\begin{array}{l}\mathrm{Fe}_{\mathrm{o}} \\
(\%)\end{array}$ & $\begin{array}{l}\mathrm{Mn}_{\mathrm{d}} \\
(\%)\end{array}$ & $\begin{array}{l}\mathrm{Mn}_{\mathrm{o}} \\
(\%)\end{array}$ \\
\hline $\mathrm{H} 1$ & 15.5 & 7.96 & 7.63 & 7.3 & 8.3 & 37.1 & 5.43 & 23.6 & 42.3 & 21.4 & & 2.40 & 1.17 & 19.0 & 0.68 & 0.54 & 0.06 \\
$\mathrm{H} 2$ & 9.07 & 8.67 & 8.11 & 2.0 & $\mathrm{bdl}$ & 72.4 & 0.42 & 11.8 & 46.8 & 9.83 & & 1.10 & 0.31 & 8.67 & 0.20 & 0.13 & 0.02 \\
$\mathrm{H} 3$ & 3.39 & 8.79 & 8.24 & 1.7 & $\mathrm{bdl}$ & 92.3 & 0.38 & 7.70 & 64.0 & 2.94 & & 0.60 & 0.15 & 3.29 & 0.01 & 0.01 & 0.00 \\
$\mathrm{H} 4$ & 16.2 & 6.74 & 5.80 & 0.9 & 6.5 & bdl & 0.61 & 19.0 & 24.3 & 9.91 & & 1.90 & 0.38 & 17.9 & 0.52 & 0.32 & 0.18 \\
$\mathrm{H} 5$ & 12.3 & 7.20 & 6.72 & 13 & 28.1 & bdl & 8.22 & 23.8 & 33.3 & 25.9 & & 1.90 & 0.50 & 19.4 & 0.65 & 0.85 & 0.41 \\
$\mathrm{H} 6$ & 4.39 & 5.87 & 4.58 & 0.5 & 1.1 & bdl & 0.49 & 8.31 & 21.2 & 3.83 & & 0.90 & 0.27 & 7.77 & 1.00 & 0.15 & 0.09 \\
$\mathrm{H} 7$ & 25.7 & 7.03 & 5.86 & 1.6 & bdl & 0.92 & 0.66 & 54.7 & 15.3 & 15.5 & & 5.10 & 0.73 & 82.6 & 0.78 & 0.13 & 0.03 \\
\hline
\end{tabular}

Free forms of $\mathrm{Al}_{\mathrm{d}}, \mathrm{Fe}_{\mathrm{d}}$ and $\mathrm{Mn}_{\mathrm{d}}$ and amorphous forms of $\mathrm{Al}_{\mathrm{o}}, \mathrm{Fe}_{\mathrm{o}}$ and $\mathrm{Mn}_{\mathrm{o}}$

$I$ ionic strength, $P$ available phosphorus content, $O C$ organic carbon content, $C E C$ cation exchange capacity, $b d l$ below detection limit

${ }^{\text {a }}$ Total As background

added to each container. The containers were kept in an incubator chamber at $20^{\circ} \mathrm{C}$ with $12 \mathrm{~h}$ of light per day. Container weights were monitored weekly to maintain moisture content, and additional food was added when required.

After 4 weeks, test containers were emptied into a tray, and surviving adults were collected by hand sorting, cleaned and weighed. Surviving earthworms were placed on moist filter paper for approximately $24 \mathrm{~h}$ to void their gut contents, following Arnold and Hodson (2007). After weighing, they were freeze-dried and stored for analysis. Soils, which contained cocoons, were returned to their respective containers and incubated for another 4 weeks controlling the water content weekly. After this period, the containers were placed in a water bath at $60{ }^{\circ} \mathrm{C}$, forcing juveniles to emerge to the surface, where they were counted.

\section{Arsenic analysis}

Total arsenic background concentrations in soils and earthworm tissues (AsE) were determined after digestion in a mixture of concentrated $\mathrm{HNO}_{3}: \mathrm{HCl}(4: 1)$. Watersoluble As concentration in soil (AsW) was determined from soil:water extracts (1:1 ratio) after $24 \mathrm{~h}$ equilibrium with shaking (Romero-Freire et al. 2014, 2015; Fotovat and Naidu, 1998). In all cases, As was measured by inductively coupled plasma-mass spectrometry (ICP-MS) in a ICP-MS NexION 300D spectrometer. Instrumental drift was monitored by regularly running standard element solutions between samples. For calibration, two sets of standards containing the analyte of interest at five concentrations were prepared using rhodium as an internal standard. Procedural blanks were included for estimating the detection limit $(3 \times \sigma ; n=6)$ which was $<0.21 \mu \mathrm{g} / \mathrm{L}$ for As. The analytical precision was better than $\pm 5 \%$ in all cases. The accuracy of the method was confirmed by analysing standard reference material SRM2711 Montana Soil (US NIST 2003). Total As concentrations (AsT) in spiked soils were checked using portable X-ray fluorescence (PXRF) (Martín Peinado et al. 2010), and measured concentrations ranged between 80 and $97 \%$ (average \pm SD $92 \pm 5 \% ; n=34$ ) of the nominal values.

\section{Data analysis}

Soil-water partition coefficient $(\mathrm{Kp})$ was calculated as the ratio of the total As concentration in soil (AsT in $\mathrm{mg} \mathrm{kg}^{-1}$ dry soil) and the water-soluble As concentration (AsW in $\mathrm{mg} \mathrm{L}^{-1}$ ) and expressed as litres per kilogramme (Blaser et al. 2000). Biotasoil accumulation factors (BSAF) for the uptake of As in the earthworms after reaching the steady state (OECD 317, 2010) were calculated by dividing concentrations in the surviving animals (AsE; in $\mathrm{mg} \mathrm{As} \mathrm{kg}^{-1}$ earthworm dry weight) by total concentrations in the tested soils (AsT; in $\mathrm{mg} \mathrm{kg}^{-1}$ dry soil) (Peijnenburg et al. 1999). Biota-water accumulation factors (BWAF) were calculated by dividing AsE by water-soluble As concentrations (AsW; in $\mathrm{mg} \mathrm{L}^{-1}$ ) (Peijnenburg et al. 1999). Lethal concentrations causing $10 \%$ mortality $\left(\mathrm{LC}_{10}\right)$ and effective concentrations causing 50 and $10 \%$ reduction of juvenile production $\left(\mathrm{EC}_{50}, \mathrm{EC}_{10}\right)$ and their corresponding $95 \%$ confidence intervals were calculated by fitting a loglogistic dose-response model to the data (Doelman and Haanstra 1989) for soil samples which showed a doseresponse relationship with AsT, AsW and/or AsE.

To assess As toxicity for earthworm exposition, mortality (M) was calculated as the percentage of worms that died during the 4-week exposure period for each soil and treatment in relation to the control; weight variation (W) was calculated as the percentage of variation in the surviving earthworms recovered after 4 weeks in relation to the initial weight and recalculated in relation to the control soils; juvenile production (J) was calculated from the number of juveniles produced per worm per week and expressed as the percentage in relation to the control.

Normal distribution of the data was verified with a Kolmogorov-Smirnov test. Significant differences were 
determined by ANOVA, and multiple comparison analyses were performed with Tukey HSD test $(p<0.05)$. To study the influence of soil properties on accumulation and toxicity of arsenic by E. andrei, Spearman's correlation analysis and principal component analysis (PCA) after varimax rotation were applied to discriminated different groups of variables according to statistical similarities of the normalized dataset. All these analyses were performed with a confidence level of $95 \%$ by using SPSS v.20.0 (SPSS Inc. Chicago, USA).

\section{Results}

\section{Water-soluble arsenic concentrations and soil properties}

Water-soluble As concentrations showed a dose-related increase and were significantly higher $(p<0.05)$ at the highest As concentrations added $\left(>300 \mathrm{mg} \mathrm{kg}^{-1}\right)$ for all studied soils and also differed between the tested soils (Table 2). The lowest water-soluble As concentration was found in the iron-rich soil H7 (red Mediterranean soil) with $3.34 \mathrm{mg} \mathrm{As} \mathrm{kg}^{-1}$ soil extracted at the highest concentration tested $\left(600 \mathrm{mg} \mathrm{As} \mathrm{kg}^{-1}\right.$ soil). Soils rich in organic carbon (H1 and H5) also showed low water-soluble arsenic concentrations, with extractions of 82.9 and $106 \mathrm{mg} \mathrm{As} \mathrm{kg}^{-1}$ soil, respectively, at the highest exposure concentrations. In soils $\mathrm{H} 4$ and H6, which are slightly acidic, non-carbonated and had low ionic strength, 116 and $118 \mathrm{mg} \mathrm{kg}^{-1}$ of the As were water-soluble at $600 \mathrm{mg} \mathrm{As} \mathrm{kg}^{-1}$, respectively. Soils with the highest $\mathrm{CaCO}_{3}$ content and basic $\mathrm{pH}(\mathrm{H} 2$ and $\mathrm{H} 3)$ had the highest water-soluble arsenic concentrations (271 and $337 \mathrm{mg} \mathrm{As} \mathrm{kg}{ }^{-1}$ soil, respectively). Table 2 also includes the partition coefficient $(\mathrm{Kp})$ for As in the different soils. Kp showed a significance difference among treatments in the different studied soils. Higher Kp values appeared in control soils; however, this was not the case in soils $\mathrm{H} 4$ and $\mathrm{H} 7$, where high values appeared at the lower As treatment levels.

The factorial analysis expressed as a principal component analysis (PCA) between AsT, AsW, Kp and some of the main soil properties showed that $62.3 \%$ of the variance was explained by two components (Fig. 1). The arsenic forms (watersoluble and total) were grouped with $\mathrm{pHH}_{2} \mathrm{O}$ and $\mathrm{CaCO}_{3}$ content. In component $1, \mathrm{Kp}$ was strongly related with clay content, ionic strength (I) and free forms of $\mathrm{Al}$ and $\mathrm{Fe}$, while in component 2, phosphorous content (P), free forms of Mn, organic carbon (OC) content and cation exchange capacity (CEC) were grouped together.

\section{Arsenic bioaccumulation}

Internal As concentrations in earthworms (AsE) increased with increasing soil As concentrations (Table 2). In earthworms from control soils, average arsenic concentration was
$32.8( \pm 16.3) \mu \mathrm{g} \mathrm{As} \mathrm{g}^{-1}$ dry weight $(n=21)$. When exposed to $600 \mathrm{mg} \mathrm{As} \mathrm{kg}{ }^{-1}$ dry weight, the earthworms showed the highest internal concentration in soils $\mathrm{H} 1, \mathrm{H} 2, \mathrm{H} 4$ and $\mathrm{H} 7$, ranging from $1019 \mu \mathrm{g} \mathrm{As} \mathrm{g}^{-1}$ in $\mathrm{H} 7$ to $525 \mu \mathrm{g} \mathrm{As} \mathrm{g}^{-1}$ in $\mathrm{H} 2$, meanwhile soils $\mathrm{H} 3$ and $\mathrm{H} 5$ presented the highest AsE (762 and $768 \mu \mathrm{g} \mathrm{As} \mathrm{g}^{-1}$, respectively) in the treatment of $300 \mathrm{mg} \mathrm{As} \mathrm{kg}^{-1}$ dry weight. In soil $\mathrm{H} 6$, the maximum value of AsE was $740 \mu \mathrm{g} \mathrm{As} \mathrm{g}^{-1}$ in the treatment of $100 \mathrm{mg} \mathrm{As} \mathrm{kg}^{-1}$, and there were no survivors at higher exposure concentrations.

Biota-soil accumulation factor (BSAF) ranged between 0.93 and $7.67 \mathrm{~kg}$ soil kg${ }^{-1}$ earthworm in control soils. While for the highest contamination level $\left(600 \mathrm{mg} \mathrm{As} \mathrm{kg}^{-1}\right)$, values ranged between 0.87 and 1.93, with the exception of soils $\mathrm{H} 3$ and $\mathrm{H} 6$ in which there were no survivors for this treatment. In general, BSAF tended to decrease with increasing As concentration in soil (regardless of controls), except for soils H1 and $\mathrm{H} 2$, with no significant changes between treatments, and $\mathrm{H} 7$ where BSAF increased with increasing AsT (Table 2). Biotawater accumulation factor (BWAF) ranged between 258 and $9710 \mathrm{~L} \mathrm{~kg}^{-1}$ earthworm in the controls, while for the highest As treatment BWAF, values were ranged from 1.96 in $\mathrm{H} 2$ to 362 in $\mathrm{H} 7$ soils. In general, BWAF decreased with the increase in AsW in relation to the control, except for soils $\mathrm{H} 4$ and $\mathrm{H} 7$ in which the maximum BWAF values were found at the lowest As concentrations added (treatments of 50 and $100 \mathrm{mg} \mathrm{As} \mathrm{kg}^{-1}$ ) (Table 2).

\section{Arsenic toxicity in earthworms}

According to the OECD 222 guideline, the toxicity test is valid when earthworm mortality in the control is less than $10 \%$ and more than 30 juveniles are produced in each replicate control. Based on this, all tests fulfilled these requirements except soil $\mathrm{H} 1$ for juvenile production, in which very low values were reached. Earthworm mortality (M) after 4 weeks was quite differently affected by arsenic contamination according to the different soil types, with less or equal than $7 \%$ mortality in soils $\mathrm{H} 2$, less or equal than $20 \%$ mortality in soils $\mathrm{H} 4$ and H7, and a dose-related decrease in soils $\mathrm{H} 1, \mathrm{H} 3, \mathrm{H} 5$ and H6. Mortality was only higher than $50 \%$ in soils $\mathrm{H} 3$ and H6 (Table 3) at concentrations added of $300 \mathrm{mg} \mathrm{As} \mathrm{kg}{ }^{-1}$ soil.

The average individual earthworms weight in the controls at the beginning of the exposures was $501 \pm 72 \mathrm{mg}( \pm \mathrm{SD} ; n=$ 210), while after 4 weeks of incubation, it was $420 \pm 65 \mathrm{mg}$. In the As-spiked soils, earthworm weights showed variation trends that were not always dose-related. In some cases, there was a trend of increasing earthworm weights in relation to the control (W) at higher As concentrations, which was significant for soils H1, H5 and H6. In the other soils, earthworm weight showed no significant dose-related variation compared to the control (Table 3). 
Table 2 Mean water-soluble arsenic concentrations (AsW; mg $\mathrm{As} \mathrm{kg}^{-1}$ soil), partition coefficient calculated as the ratio of the total As concentration in soil and the water-soluble As concentration expressed as milligrammes per litre As $\left(\mathrm{Kp} ; \mathrm{L} \mathrm{kg}^{-1}\right)$, arsenic concentrations in earthworms (Eisenia andrei) after 4 weeks exposure (AsE; $\mu \mathrm{g} \mathrm{As} \mathrm{g}^{-1}$ dry body weight), biota-soil accumulation factors (BSAF; $\mathrm{kg}$ soil $\mathrm{kg}^{-1}$ earthworm); biotawater accumulation factors (BWAF; $\mathrm{L} \mathrm{kg}^{-1}$ earthworm)

\begin{tabular}{|c|c|c|c|c|c|c|}
\hline Soil & $\begin{array}{l}\text { As nominal } \\
\mathrm{mg} \mathrm{kg}^{-1}\end{array}$ & $\begin{array}{l}\text { AsW } \\
\mathrm{mg} \mathrm{kg}^{-1}\end{array}$ & $\begin{array}{l}\mathrm{Kp} \\
\mathrm{L} \mathrm{kg}^{-1}\end{array}$ & $\begin{array}{l}\mathrm{AsE} \\
\mu \mathrm{g} \mathrm{g}^{-1} \text { d.w. }\end{array}$ & $\begin{array}{l}\text { BSAF } \\
\mathrm{kg} \text { soil kg }^{-1} \text { worm }\end{array}$ & $\begin{array}{l}\text { BWAF } \\
\mathrm{L} \mathrm{kg}^{-1} \text { worm }\end{array}$ \\
\hline \multirow[t]{5}{*}{ H1 } & 0 & $0.023 \mathrm{a}$ & $689 \mathrm{~b}$ & $32.5 \mathrm{a}$ & $2.06 \mathrm{a}$ & $1376 \mathrm{~b}$ \\
\hline & 50 & $0.49 \mathrm{a}$ & $134 \mathrm{a}$ & $113 \mathrm{ab}$ & $1.73 \mathrm{a}$ & $228 \mathrm{a}$ \\
\hline & 100 & $1.78 \mathrm{a}$ & $64.9 \mathrm{a}$ & $170 \mathrm{ab}$ & $1.50 \mathrm{a}$ & $94.9 \mathrm{a}$ \\
\hline & 300 & $22.4 \mathrm{~b}$ & $14.1 \mathrm{a}$ & $504 b$ & $1.60 \mathrm{a}$ & $22.5 \mathrm{a}$ \\
\hline & 600 & $82.9 \mathrm{c}$ & $7.5 \mathrm{a}$ & $972 \mathrm{c}$ & $1.56 \mathrm{a}$ & $11.6 \mathrm{a}$ \\
\hline \multirow[t]{5}{*}{$\mathrm{H} 2$} & 0 & $0.007 \mathrm{a}$ & $1295 \mathrm{~d}$ & $67.9 \mathrm{a}$ & $7.49 \mathrm{~b}$ & $9710 \mathrm{~b}$ \\
\hline & 50 & $0.96 a$ & $61.8 \mathrm{c}$ & $96.7 \mathrm{a}$ & $1.63 \mathrm{a}$ & $103 a$ \\
\hline & 100 & $6.45 \mathrm{a}$ & $16.9 \mathrm{~b}$ & $182 \mathrm{a}$ & $1.66 \mathrm{a}$ & $28.2 \mathrm{a}$ \\
\hline & 300 & $85.3 \mathrm{~b}$ & $3.63 \mathrm{a}$ & $326 a b$ & $1.07 \mathrm{a}$ & $3.83 \mathrm{a}$ \\
\hline & 600 & $271 \mathrm{c}$ & $2.27 \mathrm{a}$ & $525 \mathrm{~b}$ & $0.87 \mathrm{a}$ & $1.96 \mathrm{a}$ \\
\hline \multirow[t]{5}{*}{ H3 } & 0 & $0.010 \mathrm{a}$ & $339 d$ & $26.01 \mathrm{a}$ & $7.67 \mathrm{c}$ & $2600 \mathrm{~b}$ \\
\hline & 50 & $6.56 \mathrm{a}$ & $8.17 \mathrm{c}$ & $482 b$ & $9.03 \mathrm{bc}$ & $73.9 \mathrm{a}$ \\
\hline & 100 & $29.5 \mathrm{a}$ & $3.5 b$ & $594 b c$ & $5.73 b$ & $20.2 \mathrm{a}$ \\
\hline & 300 & $153 b$ & $2.00 \mathrm{a}$ & $762 \mathrm{c}$ & $2.53 \mathrm{a}$ & $5.0 \mathrm{a}$ \\
\hline & 600 & $337 \mathrm{c}$ & $1.80 \mathrm{a}$ & ns & ns & ns \\
\hline \multirow[t]{5}{*}{ H4 } & 0 & $0.077 \mathrm{a}$ & $218 b$ & $18.8 \mathrm{a}$ & $1.17 \mathrm{a}$ & $258 \mathrm{a}$ \\
\hline & 50 & $0.12 \mathrm{a}$ & $579 \mathrm{c}$ & $278 \mathrm{ab}$ & $4.20 \mathrm{~b}$ & $2482 b$ \\
\hline & 100 & $0.57 \mathrm{a}$ & $205 b$ & $516 \mathrm{c}$ & $4.43 b$ & $923 a$ \\
\hline & 300 & $23.1 \mathrm{~b}$ & $13.8 \mathrm{a}$ & $667 \mathrm{c}$ & $2.11 \mathrm{a}$ & $29.4 \mathrm{a}$ \\
\hline & 600 & $116 \mathrm{c}$ & $5.33 \mathrm{a}$ & $718 \mathrm{c}$ & $1.16 \mathrm{a}$ & $6.2 \mathrm{a}$ \\
\hline \multirow[t]{5}{*}{ H5 } & 0 & $0.014 \mathrm{a}$ & $1022 \mathrm{~b}$ & $28.35 \mathrm{a}$ & $2.33 b$ & $2311 b$ \\
\hline & 50 & $1.05 \mathrm{a}$ & $59.5 \mathrm{a}$ & $600 \mathrm{~b}$ & $9.63 \mathrm{~d}$ & $573 a$ \\
\hline & 100 & $3.44 \mathrm{a}$ & $32.6 \mathrm{a}$ & $688 \mathrm{bc}$ & $6.13 c$ & $200 \mathrm{a}$ \\
\hline & 300 & $29.3 b$ & $10.6 \mathrm{a}$ & $768 \mathrm{c}$ & $2.43 b$ & $26.2 \mathrm{a}$ \\
\hline & 600 & $106 c$ & $5.83 \mathrm{a}$ & $609 b$ & $0.99 \mathrm{a}$ & $5.83 \mathrm{a}$ \\
\hline \multirow[t]{5}{*}{ H6 } & 0 & $0.010 \mathrm{a}$ & $439 a$ & $32.2 \mathrm{a}$ & $7.33 \mathrm{a}$ & $3219 \mathrm{c}$ \\
\hline & 50 & $0.36 \mathrm{a}$ & $154.2 \mathrm{~b}$ & $606 b$ & $11.1 \mathrm{~b}$ & $1743 b$ \\
\hline & 100 & $1.08 \mathrm{a}$ & $97.9 \mathrm{c}$ & $740 \mathrm{~b}$ & $7.09 \mathrm{a}$ & $698 \mathrm{a}$ \\
\hline & 300 & $23.1 \mathrm{~b}$ & $14.7 \mathrm{~d}$ & $\mathrm{~ns}$ & ns & ns \\
\hline & 600 & $118 \mathrm{c}$ & $5.13 \mathrm{~d}$ & ns & ns & ns \\
\hline \multirow[t]{5}{*}{ H7 } & 0 & $0.010 \mathrm{a}$ & $2566 \mathrm{a}$ & $23.3 \mathrm{a}$ & $0.93 \mathrm{ab}$ & $2334 \mathrm{ab}$ \\
\hline & 50 & $0.013 \mathrm{a}$ & $6305 b$ & $64.2 \mathrm{a}$ & $0.83 \mathrm{a}$ & $5426 \mathrm{c}$ \\
\hline & 100 & $0.023 \mathrm{a}$ & $5585 \mathrm{~b}$ & $122 \mathrm{a}$ & $0.97 \mathrm{ab}$ & $5411 b c$ \\
\hline & 300 & $0.28 \mathrm{~b}$ & $1189 a$ & $540 \mathrm{~b}$ & $1.67 \mathrm{ab}$ & $1953 b$ \\
\hline & 600 & $3.34 \mathrm{c}$ & $188 \mathrm{a}$ & $1019 \mathrm{c}$ & $1.93 b$ & $362 a$ \\
\hline
\end{tabular}

As nominal: total arsenic added to the soil in milligrammes per kilogramme. See Table 1 for soil properties. Lowercase letters show significant differences among treatments for each soil (Tukey HSD test, $p<0.05$ )

ns no survival
Juvenile production $(\mathrm{J})$ in relation to the control showed a decrease with increasing arsenic concentration for most studied soils. Juvenile reduction was significantly different from the control samples $(p<0.05)$ at the lowest treatment (50 mg As kg ${ }^{-1}$ ) for the soils $\mathrm{H} 3, \mathrm{H} 5$ and $\mathrm{H} 6$, and at the treatment $100 \mathrm{mg} \mathrm{As} \mathrm{kg}{ }^{-1}$ added for soils $\mathrm{H} 4$ and H7. Soil $\mathrm{H} 2$ showed an anomalous behaviour with the highest juvenile number in relation to the control at 100 and $300 \mathrm{mg} \mathrm{As} \mathrm{kg}^{-1}$ soil (Table 3).
The results of the toxicity endpoints (lethal and effective concentrations) are shown in Table 4. For soils H2, H4 and $\mathrm{H} 7$, the arsenic concentrations used in this study in relation to earthworm survival (LC10) did not show toxicity response variation in relation to the control soils. LC10 values calculated from total As concentrations (AsT) ranged from $606 \mathrm{mg} \mathrm{As} \mathrm{kg}{ }^{-1}$ dry soil for H1 (close to the highest As concentration tested) to $31 \mathrm{mg} \mathrm{kg}^{-1}$ dry soil for H6. LC10 based on water-soluble As concentrations (AsW) was also 
Fig. 1 Principal component analysis (PCA) after varimax rotation including As forms (AsT total arsenic concentrations, $A s W$ water-soluble arsenic concentrations), partition coefficient $(K p)$ and the main soil properties (I: ionic strength; $F e_{d}$, $M n_{d}$ and $A l_{d}$ : free forms of iron, manganese and aluminium; $C E C$ : cation exchange capacity; $O C$ : organic carbon content; $P$ : available phosphorous). Accumulate variance explained for component $1=32.8 \%$ and for component $2=62.3 \%$

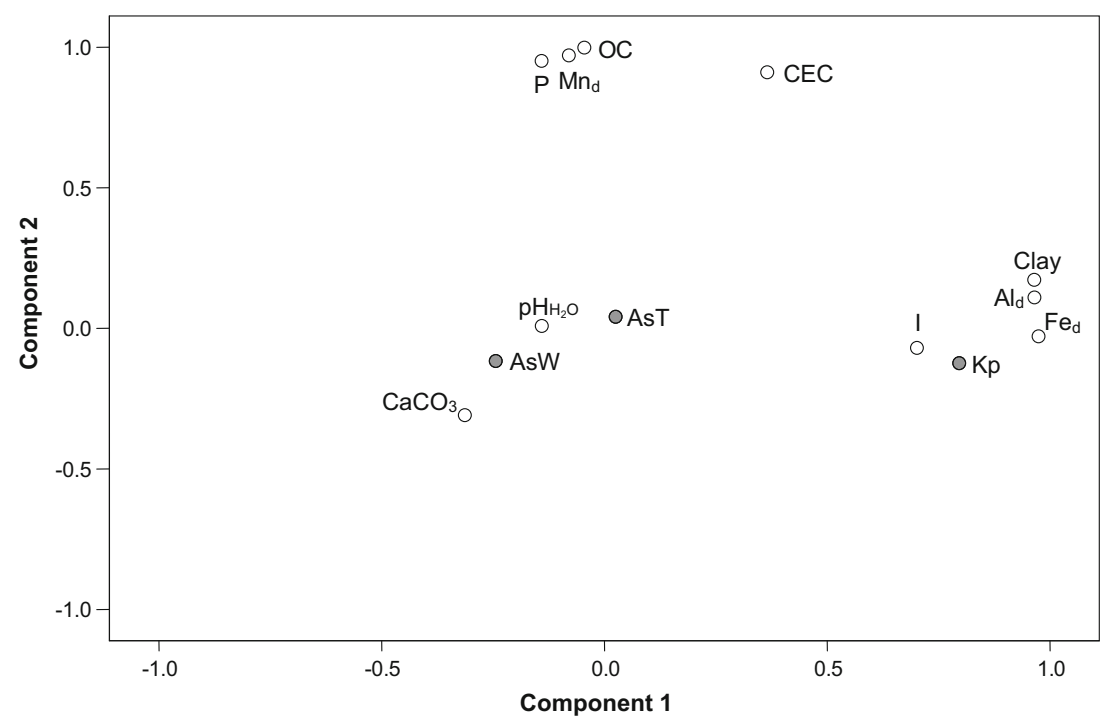

highest for H1 soil (82 $\left.\mathrm{mg} \mathrm{kg}^{-1}\right)$ and lowest for soil H6 with a value of $0.089 \mathrm{mg} \mathrm{kg}^{-1}$ (Table 4).

Earthworm reproduction based on juvenile production data was more sensitive than survival data. For soils $\mathrm{H} 1, \mathrm{H} 2$ and H6, no toxicity endpoints were calculated because no doserelated variation was observed. Soils H4 and H7 showed the lowest toxicity according to juvenile production for AsT, with

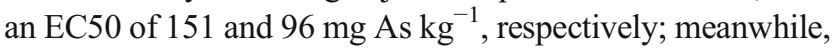
arsenic toxicity was highest in soil H5 with EC50 and EC10 values of 56 and $26 \mathrm{mg} \mathrm{kg}^{-1}$ (AsT), respectively. However, in relation to water-soluble concentrations (AsW), soil H3 was the least toxic (EC50 of $8.4 \mathrm{mg} \mathrm{As} \mathrm{kg}^{-1}$ ), and soil $\mathrm{H} 7$ was the most toxic for juvenile production (EC50 of $0.013 \mathrm{mg} \mathrm{As} \mathrm{kg}^{-1}$ ) (Table 4).

Toxicity endpoints were also calculated by the internal As concentrations (AsE) in the surviving earthworms. This variable showed lower differences between soils than the endpoints calculated from AsT and AsW. LC10 based on internal As concentrations was lowest in soil H6 (LC10 $356 \mu \mathrm{g} \mathrm{g}^{-1}$ dry earthworm) and highest in $\mathrm{H} 1$ (LC10 $>793 \mu \mathrm{g} \mathrm{g}^{-1}$ dry earthworm). For juvenile production, EC50 related to AsE was lowest for soil H7, with values of $84 \mu \mathrm{g} \mathrm{g}^{-1}$ dry earthworm, and the highest value was for H5 soil (584 $\mu \mathrm{g} \mathrm{g}^{-1}$ dry earthworm) (Table 4).

\section{As bioavailability and toxicity in relation to soil properties}

Spearman correlation between the variables related to As bioavailability and toxicity (Table 5) showed that AsE was directly correlated with AsT and AsW, and inversely with Kp; meanwhile, biota-soil accumulation (BSAF) was only inversely correlated with AsT. Biota-water accumulation factor (BWAF) was inversely correlated with AsT, AsW and AsE, and directly with $\mathrm{Kp}$. In relation to earthworm response, earthworm mortality $(\mathrm{M})$ was directly related to AsT and AsE concentrations, and earthworm weight variation (W) was positively correlated with AsE and mortality. Juvenile production (J) showed a negative correlation with AsT, AsW and AsE and also with mortality and weight variation, while Kp was positively correlated with juvenile production.

PCA with the toxicity endpoints and the main soil variables of this study showed that $81.3 \%$ of the variance was explained by a total of five components (Table 6). The responses of the earthworm to As toxicity (mortality, weight variation and juvenile production) were grouped in component 2 with the As forms (AsT, AsW and AsE) with a direct relation in all cases except in juvenile production which showed an inverse relation with all these components. Component 1 grouped some of the main soil properties like organic carbon content (OC), available phosphorous content $(\mathrm{P})$, amorphous $\mathrm{Mn}$ forms $\left(\mathrm{Mn}_{\mathrm{o}}\right)$ and cation exchange capacity (CEC). Component 3 grouped ionic strength (I) and amorphous iron forms $\left(\mathrm{Fe}_{\mathrm{o}}\right)$ together and inversely related with $\mathrm{pHH}_{2} \mathrm{O}$; weight variation of the earthworms (W) as well as the AsW was also grouped in this component with positive and negative coefficients, respectively, but with a low load in this component. BSAF was included in component 4 and negatively related with AsT, CEC, clay content and amorphous $\mathrm{Al}$ forms $\left(\mathrm{Al}_{\mathrm{o}}\right)$. Finally, BWAF, Kp and clay content were included in component 5 with a positive relation.

\section{Discussion}

According to the arsenic mobility in relation to soil properties and constituents, iron oxides have been widely described as the main active constituents determining As retention in soil (Fitz and Wenzel 2002), which coincides with our study where the lowest water-soluble As concentrations were found in the iron-rich soil (H7). Moreover, As distribution between the 


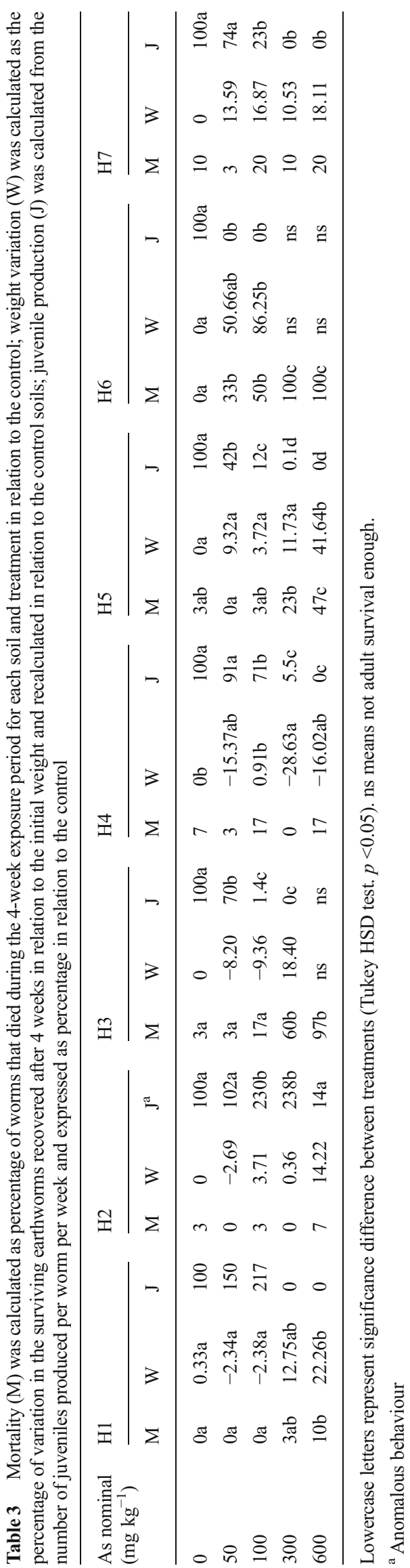

soluble and the solid phases is related also to organic carbon content (Yang et al. 2002). In our case, sample H1 and H5 (with the highest organic carbon contents) showed low values of AsW for the highest treatment (Table 2). A previous study with the same soils treated with the same As concentrations and conditions (Romero-Freire et al. 2014) confirmed the inverse correlation of AsW concentrations with OC content in the treatments with high concentrations of As added. Furthermore, it is known that the solubility of arsenic decreases when ionic strength increases (Acosta et al. 2011), and in our study, soils H6 and H4 (with the lowest ionic strength) presented low AsW concentrations in relation to the total As content. The highest AsW concentrations were found in the soils with the highest $\mathrm{CaCO}_{3}$ content and basic $\mathrm{pH}(\mathrm{H} 2$ and $\mathrm{H} 3)$, which is in accordance with other studies revealing that under certain conditions a higher $\mathrm{pH}$ may enhance As solubilization (Simon et al. 2010).

Partition coefficient $(\mathrm{Kp})$ is crucial to estimate the potential for the adsorption of dissolved arsenic in contact with soil (USEPA 1999) and is strongly influenced by soil parameters. However, there is no consensus in literature to state these parameters due to it is obtained from a wide range of soil to water ratios (Sauvé et al. 2000), hindering the comparison among studies. Nevertheless, $\mathrm{Kp}$ is a key parameter to compare in our study soils under the same testing conditions and arsenic extraction method. Our study showed that Kp was directly correlated with iron and aluminium forms as well as ionic strength and clay content. Other studies (Song et al. 2006; Romero-Freire et al. 2014) showed that some of these properties play an important role in the As solubility which are strongly related to this coefficient. Sauvé et al. (2000) also reported some other soil properties like $\mathrm{pH}$ or $\mathrm{OC}$ as essentials to predict $\mathrm{Kp}$ values due to their influence on As solubility.

Internal arsenic concentrations in earthworms (AsE) varied between soils and increased with increasing exposure both AsT and AsW concentrations. AsE reported by other authors showed a wide range of values; Janssen et al. (1997) showed for $E$. andrei, in 20 different Dutch soils, a range from 2.99 to $65.2 \mu \mathrm{g} \mathrm{As} \mathrm{g}^{-1}$ dry weight; García-Gómez et al. (2014) found for control soils an average of $18 \mu \mathrm{g} \mathrm{As} \mathrm{g}^{-1}$ dry weight for Eisenia fetida; and Langdon et al. (2003) reported values between $3 \mu \mathrm{g} \mathrm{As} \mathrm{g}^{-1}$ (soil total concentration $5 \mathrm{mg} \mathrm{As} \mathrm{kg}^{-1}$ ) and $900 \mu \mathrm{g} \mathrm{As} \mathrm{g}^{-1}$ (soil total concentration $87 \mathrm{mg} \mathrm{As} \mathrm{kg}^{-1}$ ) based on a review for different species of earthworms. However, other authors showed lower concentrations. Peijnenburg et al. (1999) found in soils without arsenic pollution a mean tissue concentration of $3.75 \mu \mathrm{g} \mathrm{As} \mathrm{g}{ }^{-1}$ dry weight for E. andrei, and Beyer et al. (1985) gave an internal arsenic concentration of 5-6 $\mu \mathrm{g} \mathrm{As} \mathrm{g}^{-1}$ for E. fetida. In earthworms of the genus Eisenoides, Beyer and Cromartie (1987) found an internal concentration of $0.17-1.5 \mu \mathrm{g} \mathrm{As} \mathrm{g}^{-1}$ dry weight, suggesting that different earthworm species show great 


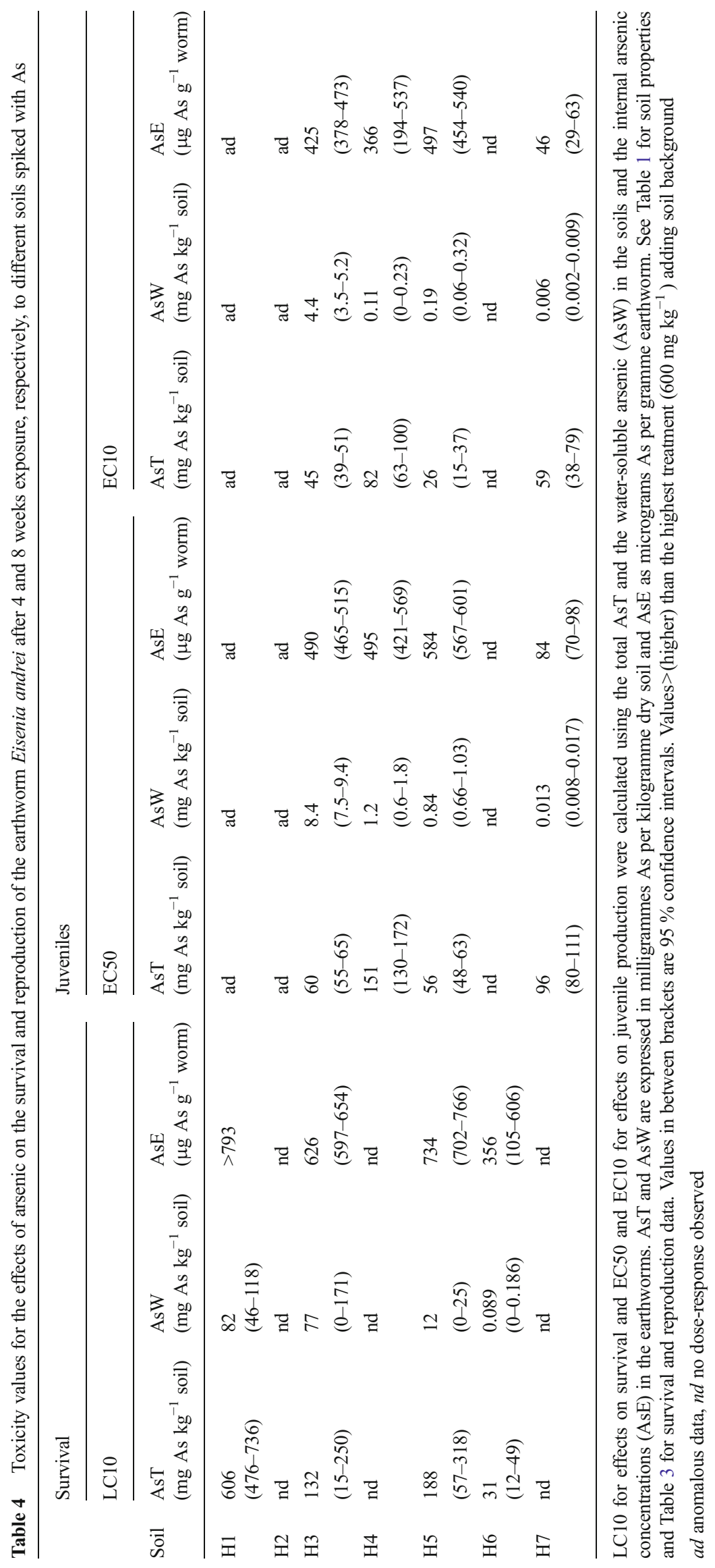


Table 5 Correlation coefficients (Spearman) between total arsenic (AsT), water extractable As (AsW), partition coefficient (Kp), internal As concentrations in the earthworms (AsE), biota-soil accumulation factors (BSAF); biota-water accumulation factors (BWAF) and earthworm (Eisenia andrei) responses: mortality $(\mathrm{M})$, weight variation (W) and juvenile production $(\mathrm{J})$

\begin{tabular}{|c|c|c|c|c|c|c|c|c|c|}
\hline & \multicolumn{9}{|c|}{ Spearman correlations } \\
\hline & AsT & AsW & $\mathrm{Kp}$ & AsE & BSAF & BWAF & M & $\mathrm{W}$ & $\mathrm{J}$ \\
\hline AsT (mg As kg ${ }^{-1}$ soil) & 1 & $0.777 * *$ & $-0.581 * *$ & $0.747 * *$ & $-0.459 * *$ & $-0.633^{* *}$ & $0.431^{*}$ & & $-0.647 * *$ \\
\hline AsW (mg As kg ${ }^{-1}$ soil) & & 1 & $-0.957 * *$ & $0.759 * *$ & & $-0.953 * *$ & & & $-0.527 * *$ \\
\hline $\mathrm{Kp}\left(\mathrm{L} \mathrm{kg}^{-1}\right)$ & & & 1 & $-0.645^{* *}$ & & $0.944 * *$ & & & $0.399 *$ \\
\hline AsE ( $\mu \mathrm{g} \mathrm{As} \mathrm{g}^{-1}$ earthworm) & & & & 1 & & $-0.576^{* *}$ & $0.533^{* *}$ & $0.410^{*}$ & $-0.781 * *$ \\
\hline BSAF (kg soil kg-1 earthworm) & & & & & 1 & & & & \\
\hline BWAF ( $\mathrm{L} \mathrm{kg}^{-1}$ earthworm) & & & & & & 1 & & & \\
\hline M (\%) & & & & & & & 1 & $0.551 * *$ & $-0.734^{* *}$ \\
\hline W (\%) & & & & & & & & 1 & $-0.436^{* *}$ \\
\hline $\mathrm{J}(\%)$ & & & & & & & & & 1 \\
\hline
\end{tabular}

${ }^{*} p<0.05 ; * * p<0.01$

differences in metal accumulation. Fischer and Koszorus (1992) defined the maximal accumulation capacity at $902 \mu \mathrm{g} \mathrm{As} \mathrm{g}^{-1}$ dry weight for E. fetida at sub-lethal exposure concentrations in long-term studies, which is close to our findings (maximal accumulation capacity obtained 1019士 $167 \mu \mathrm{g} \mathrm{As}^{-1}$ dry weight); at higher body concentrations, all earthworms died.
BSAF and BWAF values showed a decrease with increasing exposure levels in most of the studied soils, suggesting that arsenic is mainly autoregulated by E. andrei in these soils. Such negative relationship is common for metals (McGeer et al. 2003) and was found for molybdenum (Díez-Ortiz et al. 2010) and also for the bioaccumulation of As in E. fetida exposed to a mine soil containing high As
Table 6 PCA of rotated component matrix (varimax with Kaiser normalization) for As studied forms, the toxicity earthworm endpoints and the main variables of the studied soils

\begin{tabular}{|c|c|c|c|c|c|}
\hline & \multicolumn{5}{|c|}{ Components } \\
\hline & 1 & 2 & 3 & 4 & 5 \\
\hline AsT (mg As kg ${ }^{-1}$ soil) & & 0.711 & & 0.507 & \\
\hline AsW (mg As kg ${ }^{-1}$ soil) & & 0.618 & -0.561 & & \\
\hline $\mathrm{Kp}\left(\mathrm{L} \mathrm{kg}^{-1}\right)$ & & & & & 0.859 \\
\hline AsE ( $\mu$ g As $g^{-1}$ worm) & & 0.788 & & & \\
\hline BSAF ( $\mathrm{kg}$ soil $\mathrm{kg}^{-1}$ earthworm) & & & & -0.855 & \\
\hline BWAF ( $\mathrm{L} \mathrm{kg}^{-1}$ earthworm) & & & & & 0.825 \\
\hline $\mathrm{M}(\%)$ & & 0.781 & & & \\
\hline W (\%) & & 0.539 & 0.502 & & \\
\hline $\mathrm{J}(\%)$ & & -0.794 & & & \\
\hline $\mathrm{pH}$ (water) & & & -0.813 & & \\
\hline $\mathrm{I}\left(\mathrm{mmol} \mathrm{L}{ }^{-1}\right)$ & & & 0.628 & & \\
\hline OC $(\%)$ & 0.931 & & & & \\
\hline $\mathrm{CEC}\left(\mathrm{cmol}^{+} \mathrm{kg}^{-1}\right)$ & 0.821 & & & 0.517 & \\
\hline Clay $(\%)$ & & & & 0.661 & 0.515 \\
\hline $\mathrm{P}\left(\mathrm{mg} \mathrm{kg}^{-1}\right)$ & 0.984 & & & & \\
\hline $\mathrm{Al}_{\mathrm{o}}(\% \mathrm{o})$ & & & & 0.764 & \\
\hline $\mathrm{Mn}_{\mathrm{o}}(\% 0)$ & 0.913 & & & & \\
\hline $\mathrm{Fe}_{\mathrm{o}}(\% \mathrm{o})$ & & & 0.890 & & \\
\hline$\%$ ac.ex.var & 19.9 & 38.0 & 54.2 & 69.1 & 81.3 \\
\hline
\end{tabular}

$\%$ ac.ex.var. percent of accumulated explained variance 
concentrations (García-Gómez et al. 2014). As a consequence, the highest BSAF and BWAF values usually occur at low background levels and decrease as pollution levels increase (Williams et al. 2006), which suggests some control over As bioaccumulation. However, in soil H7, BSAF only increased at the highest total As concentration (Table 2), and in soils H4, $\mathrm{H} 5$ and H6, BSAF values showed an increase compared to the control at different treatments of As added. These cases suggest the earthworms may be capable of sequestering arsenic, leading to higher body concentrations than expected, but it remains unclear what is the mechanism of arsenic sequestration. Fischer and Koszorus (1992) reported BSAF values for As in E. fetida between 18.1 and 10.3 upon exposure to soils polluted with $23-87 \mathrm{mg} \mathrm{As} \mathrm{kg}^{-1}$ soil, which are higher than the BSAF values found in our study with $E$. andrei.

Otherwise, BWAF values decreased with increasing soil As concentrations, except for soils $\mathrm{H} 4$ and H7 (Table 2). In soil $\mathrm{H} 4$, BWAF was higher than that in the control at 50 and $100 \mathrm{mg} \mathrm{As} \mathrm{kg}^{-1}$ dry soil, while in soil $\mathrm{H} 7$, this was the case for all treatments except for the highest one (600 $\left.\mathrm{mg} \mathrm{As} \mathrm{kg}^{-1}\right)$. These findings suggest that As concentrations in earthworms did not change proportionally with changes in water-soluble arsenic induced by increasing total As concentration in soil. US EPA (2007) also reported that for As, and other nonessential metals, accumulation is nonlinear with respect to exposure concentration. In general, BWAF values could be comparable to BCF due to both factors were calculated from the watersoluble arsenic. In this sense, the bioconcentration factor (BCF) proposed by the arsenic ambient water quality criteria (AWQC), calculated from the milligramme of As in a litre of water, is $44 \mathrm{~L} \mathrm{~kg}^{-1}$, derived from BCF values of 1 for fish and 350 for oysters (Williams et al. 2006); in this paper, the highest $\mathrm{BCF}$ values reported by other studies were 1600 and $3091 \mathrm{~L} \mathrm{~kg}^{-1}$ in different fish species. Otherwise, US EPA (2003) suggested a BCF range between 150 and 10, $000 \mathrm{~L} \mathrm{~kg}^{-1}$ for different species. Results obtained in our study showed in general also high BWAF values in the range of the reported values. Our results and those obtained by other authors highlight the potential of As for bioaccumulation in food chains (McGeer et al. 2003; Williams et al. 2006), although the variation in BSAF and BWAF values in relation to the contamination levels indicates that these are no good indicators of potential environmental risks (García-Gómez et al. 2014; McGeer et al. 2003).

Earthworm mortality was correlated with AsE in our studied soils, although total or soluble arsenic concentrations in soil should better explain the mortality observed in earthworms than the body accumulation (Table 5). In fact, internal concentrations in earthworms do not necessarily correlate with the concentration at the site or the toxic action (Smith et al. 2012; García-Gómez et al. 2014). However, in some of our studied soils, mortality did not reach $50 \%$ at the highest As concentration added (600 $\mathrm{mg} \mathrm{As} \mathrm{kg}^{-1}$ soil), which reflects the importance of soil properties in reducing As availability and therefore toxicity. Mortality also was related to earthworm weight, with a significant trend to increasing earthworm weights at the highest As concentrations in soils $\mathrm{H} 1, \mathrm{H} 5$ and H6. This suggest that only the biggest earthworms survived arsenic exposure, although it might also be possible that surviving earthworms were more tolerant to As and benefitted from the reduced density and resulting higher food availability to grow bigger. Some authors suggest that earthworm weight loss could be caused primarily by soil factors, especially with soil $\mathrm{pH}$, while body metal concentrations play a minor role (Janssen et al. 1997). In our study, weight variation appeared inversely related with $\mathrm{pHH}_{2} \mathrm{O}$ (Table 6), as well as it was correlated with body As concentrations, finding the highest mortality in sample H6, soil with the lowest pH (Table 3). Moreover van Gestel et al. (1992) found that the growth of E. andrei was negatively related with reproduction, which also was found in this study (Table 5). Reproduction was more sensitive to As than survival. A large variation in juvenile production was found in the different tested soils, which could be due to the variation in soil properties (van Gestel et al. 1992). According to the OECD guideline 222, the requirements for the control sample need that the earthworm mortality should be less than $10 \%$ and juvenile production higher than 30 juveniles. Control reproduction was good in all samples with the exception of $\mathrm{H} 1$ soil, being that all earthworms were taken from the same batch, it must be concluded that the low reproduction in soil $\mathrm{H} 1$ was due to the unfavorable properties of the soil rather than to problems with the health of the tested animals. Juvenile production was negatively correlated with total and water-soluble As concentrations in the soils and with internal concentrations in the earthworms. Reproduction was lowest in soil H7, having a high clay content (which could affect water availability) and a high aluminium content, that could have influenced in the reduction of growth and juvenile production (van Gestel and Hoogerwerf 2001). Optimal environmental conditions for the reproduction of $E$. andrei are high OC content, $\mathrm{pH}\left(\mathrm{CaCl}_{2}\right)$ between 4.5 and 6.5, and a moisture content of $50 \%$ approximately of the maximum soil water holding capacity (van Gestel et al. 1992). Control conditions in soil $\mathrm{H} 5$, with a $\mathrm{pH}-\mathrm{KCl}$ of 6.7 and high organic carbon content, probably were most favourable, explaining the high number of juveniles produced in this soil, with an average of juveniles per worm per week of $6 \pm 0.6$.

The reproduction of $E$. andrei was more sensitive to arsenic than the other studied parameters; thus, the obtained toxicity endpoints could be considering more accurate. Root elongation test performed with Lactuca sativa on the same soils (Romero-Freire et al. 2014) showed similar EC10 values for total As compared with $E$. andrei reproduction in soils $\mathrm{H} 4$ and $\mathrm{H} 5$ (95 mg kg ${ }^{-1}$ and $38 \mathrm{mg} \mathrm{kg}^{-1}$ soil values for lettuce, respectively). Soil H3 showed a more restrictive EC10 for 
lettuce ( $23 \mathrm{mg} \mathrm{kg}^{-1}$ soils) than for earthworms, with values differing by a factor of two. In soil H7, lettuce was less sensitive (395 mg kg $\mathrm{g}^{-1}$ ), while earthworm reproduction gave an EC10 of $59 \mathrm{mg} \mathrm{kg}^{-1}$ in the same soil. These results highlight the influence of soil properties on arsenic bioavailability and therefore toxicity and also the importance of selecting different organisms when defining guideline values for ERA.

The study of the influence of soil properties in As toxicity for earthworm showed controversial results. Other studies with different pollutants showed $\mathrm{pH}, \mathrm{CEC}$, Ca content, $\mathrm{Mn}$ oxides, OC content, clay and silt content as the most relevant factors affecting earthworm toxicity for metals (van Gestel et al. 2011; Bradha et al. 2006; Peijnenburg et al. 2002; Janssen et al. 1997). However, our results showed that earthworm mortality in different As-treated soils was greatly explained by As soil concentration as well as internal concentration in earthworms and low influence of soil properties was found. Earthworm weight variation, also related with the studied forms of As, was observed that could increase with the rise in I strength of the soils as well as could be indirectly related with $\mathrm{pH}$ (highest $\mathrm{pH}$ lower weight variation). While juvenile production in our study decreased with higher mortality or earthworm loss body weight, the ionic strength, the $\mathrm{pH}$ and the presence of iron may be considered as soil properties which could have a role in earthworm answer to As toxicity. Our study suggested that the influence of soil properties in As solubility and availability indirectly control the influence As toxicity in earthworms. However, related to other bioassays performed with lettuce and a marine bacteria (V. fischeri) (Romero-Freire et al. 2014), soil properties had a direct influence in their toxicity answer. In this sense, As behaviour in soils and the complex pathways of incorporation in body oligochaetes should be further studied to propose robust generic environmental quality standards.

Finally, in this study, we worked with soils contaminated with concentrations chosen according to the proposed values for Andalusia representing the criteria to declare a soil as contaminated for different soil uses (Aguilar et al. 1999). The selection of these values was based on data levels proposed by other countries. However, these values do not take into account the difference in soil types. Otherwise, laboratory-spiked soils instead of field-contaminated soil were used in this study because spiked soils tend to overestimate the availability of metals in field soils (Smolders et al. 2009); therefore, the toxicity level defined can provide with more certainty the safety threshold for the environmental risk assessment (ERA). It is therefore necessary to further investigate mobility and bioavailability of $\mathrm{As}$ in the ecosystem in relation to soil properties to propose reference values useful in the declaration of contaminated areas.

\section{Conclusions}

Arsenic solubility and therefore availability were largely explained by soil properties and constituents such as $\mathrm{pH}$, calcium carbonate content, oxides forms, clay content and ionic strength of the soil solution and should be considered essential parameters influencing arsenic toxicity in soils. Internal arsenic concentration (AsE) in the studied earthworms (Eisenia andrei) increased directly with As solubility in soils which highlight the potential of As for bioaccumulation in food chains. Moreover, AsE varied between soils suggesting that earthworms could be able to sequester arsenic. Further studies to deepen in the relationships between As toxicity of earthworms and soil properties should be performed. The results of the present study in relation to the earthworm answer against As toxicity indicated that earthworm survival, body weight variation and earthworm reproduction are strongly influence by solubility of arsenic as well as AsE; therefore, soil properties could greatly reduce indirectly As bioavailability and toxicity risk for the studied oligochaeta. The comparison of the obtained results with other different organisms against As toxicity showed a high variability and therefore indicated the importance of selecting different organisms when defining guideline values for ERA.

Acknowledgments Authors thank the financial support of this work to the Project CGL 2010-19902 and Grant FPI-MICINN BES-2011045101.

Open Access This article is distributed under the terms of the Creative Commons Attribution 4.0 International License (http:// creativecommons.org/licenses/by/4.0/), which permits unrestricted use, distribution, and reproduction in any medium, provided you give appropriate credit to the original author(s) and the source, provide a link to the Creative Commons license, and indicate if changes were made.

\section{References}

Acosta JA, Martínez-Martínez S, Faz A, Arocena J (2011) Accumulations of major and trace elements in particle size fractions of soils on eight different parent materials. Geoderma 161:30-42

Aguilar J, Dorronsoro C, Galán E, Gómez JL (1999) Criterios y estándares para declarar un suelo como contaminado en Andalucía, In: Investigación y Desarrollo Medioambiental en Andalucía, Univ. Sevilla, (Ed.): 45-59

MAPA (Ministerio de Agricultura Pesca y Alimentación) (1994) Métodos Oficiales de Análisis Tomo III Secretaría General Técnica del Ministerio de Agricultura Pesca y Alimentación (MAPA) Madrid

Arnaud C, Saint-Denis M, Narbonne JF, Soler P, Ribera D (2000) Influences of different standardised test methods on biochemical responses in the earthworm Eisenia fetida andrei. Soil Biol Biochem 32:67-73

Arnold RE, Hodson ME (2007) Effect of time and mode of depuration on tissue copper concentrations of the earthworms Eisenia andrei, Lumbricus rubellus and Lumbricus terrestris. Environ Poll 148: $21-30$ 
Barth H, L'Hermite P (1987) Scientific basis for soil protection in the European community (eds). Commission of the European Communities, Brussels, Belgium. Elsevier Applied Science, London

Bengtsson G, Ek H, Rundgren S (1992) Evolutionary response of earthworms to long term metal exposure. Oikos 63:289-297

Beyer WN, Cromartie EJ (1987) A survey of Pb, Cu, Zn, Cd, Cr, As and Se in earthworms and soil from diverse sites. Environ Monit Assess 8:27-36

Beyer WN, Pattee OH, Sileo L, Hoffman DJ, Mulhern BM (1985) Metal contamination in wildlife living near two zinc smelters. Environ Pollut 38:63-86

Blaser P, Zimmermann S, Luster J, Shotyk W (2000) Critical examination of trace element enrichments and depletions in soils: $\mathrm{As}, \mathrm{Cr}, \mathrm{Cu}, \mathrm{Ni}$, $\mathrm{Pb}$, and $\mathrm{Zn}$ in Swiss forest soils. Sci Total Environ 249:257-280

Bouché A (1992) Earthworm species and ecotoxicological studies. In: Greig-Smith PW, Becker H, Edwards PJ, Heimbach F (eds) Ecotoxicology of earthworms. Intercept, Andover, pp 20-35

Bradha KD, Dayton EA, Basta NT, Schroder J, Payton M, Lanno RP (2006) Effect of soil properties on lead bioavailability and toxicity to earthworms. Environ Toxicol Chem 25:769-775

Callahan CA (1988) Earthworms as ecotoxicological assessment tools. In: Edwards C.A. Neuhauser E.F. (Eds.) Earthworms in waste and environmental assessment. SPB Academic Publishing The Hague 295-301

Cortet J, Gomot-De Vauflery A, Poinsot-Balaguer N, Gomot L, Texier C, Cluzeau D (1999) The use of invertebrate soil fauna in monitoring pollutant effects. Eur J Soil Biol 35:115-134

Díez M, Simón M, Dorronsoro C, García I, Martín F (2007) Background arsenic concentrations in Southeastern Spanish soils. Sci Total Environ 378:5-12

Díez-Ortiz M, Giska I, Groot M, Borgman EM, van Gestel CAM (2010) Influence of soil properties on molybdenum uptake and elimination kinetics in the earthworm Eisenia andrei. Chemosphere 80:10361043

Doelman P, Haanstra L (1989) Short- and long-term effect of heavy metals on phosphatase activity in soils: an ecological doseresponse model approach. Biol Fertil Soils 8:235-241

EEC (European Economic Community) (1984) Directive 79/831/ EEC Annex V part C. Method for the determination of ecotoxicity. Level 1. Earthworms: artificial soil test. Commission of the European Communities DGXI/128/82 Rev. 5 Brussels

US EPA (US Environmental Protection Agency) (1999) Understanding variation in partition coefficient $(\mathrm{Kd})$ values. Office of Air and Radiation, Report No: EPA 402-R-99-004A. Office of Air and Radiation Washington DC, USA

US EPA (US Environmental Protection Agency) (2003) Technical summary of information available on the bioaccumulation of arsenic in aquatic organisms. EPA-822-R-03-032. Office of Science and Technology \& Office of Water Washington DC USA

EPA (2007) Framework for metals risk assessment. U.S. Environmental Protection Agency. EPA120R07001

Fendorf S, La Force MJ, Li G (2004) Heavy metals in the environment. Temporal changes in soil partitioning and bioaccessibility of arsenic chromium and lead. J Environ Qual 33:2049-2055

Fischer E, Koszorus L (1992) Sub lethal effects accumulation capacities and elimination rates of $\mathrm{As} \mathrm{Hg}$ and $\mathrm{Se}$ in the manure worm Eisenia fetida (Oligochaeta Lumbricidae). Pedobiologia 36:172-178

Fitz WJ, Wenzel WW (2002) Arsenic transformations in the soil-/rhizosphere-/plant system: fundamentals and potential application to phytoremediation. J Biotechnol 99:259-278

Fleuren RHLJ, Jager T, Roelofs W, De Groot AC, Baerselman R, Peijnenburg WJGM (2003) Feeding behaviour of Eisenia andrei in two different field contaminated soils. Pedobiologia 47:670-675
Fotovat A, Naidu R (1998) Changes in composition of soil aqueous phase influence desorption and chemistry of native heavy metals in alkaline sodic and acidic soils. Geoderma 84:213-234

García-Gómez C, Esteban E, Sánchez-Pardo B, Fernández MD (2014) Assessing the ecotoxicological effects of long-term contaminated mine soils on plants and earthworms: relevance of soil (total and available) and body concentrations. Ecotoxicology 23:1195-1209

Goats GC, Edwards CA (1988) The prediction of field toxicity of chemicals to earthworms by laboratory methods. In: Edwards C.A. Neuhauser E.F. (Eds.) Earthworms in waste and environmental assessment. SPB Academic Publishing The Hague 283-294

Holmgren GGS (1967) A rapid citrate-dithionite extractable iron procedure. Soil Sci Soc Am Proc 31:210-211

Janssen RPT, Posthuma L, Baerselman R, Den Hollander HA, van Veen RPM, Peijnenburg WJGM (1997) Equililbrium partioning of heavy metals in Dutch field soils. 2. Prediction of metal accumulation in earthworms. Environ Toxicol Chem 16:2479-2488

Kabata-Pendias A, Pendias H (2001) Trace elements in soils and plants (3rd edition). CRC Press, Boca Raton Florida

Langdon CJ, Piearce TG, Meharg AA, Semple KT (2003) Interactions between earthworms and arsenic in the soil environment: a review. Environ Pollut 124:361-373

Martín Peinado F, Morales Ruano S, Bagur González MG, Estepa Molina C (2010) A rapid field procedure for screening trace elements in polluted soil using portable X-ray fluorescence (PXRF). Geoderma 159:76-82

Martín Peinado FJ, Romero Freire A, Arco Lázaro E, Sierra Aragón M, Ortiz Bernad I, Abbaslou H (2012) Assessment of arsenic toxicity in spiked soils and water solutions by the use of bioassays. Spanish J Soil Sci 2:45-56

Martín F, Simón M, Arco E, Romero A, Dorronsoro C (2012) Arsenic behaviour in polluted soils after remediation activities. Soil health and land use management. Maria C. Hernandez-Soriano (Ed.) ISBN: 978-953-307-614-0 InTech

McGeer JC, Brix KV, Skeaff JM, DeForest DK, Brigham SI, Adams WJ, Green A (2003) Inverse relationship between bioconcentration factor and exposure concentration for metals: implications for hazard assessment of metals in the aquatic environment. Environ Toxicol Chem 22:1017-1037

Nahmani J, Hodson ME, Black S (2007) A review of studies performed to assess metal uptake by earthworms. Environ Pollut 145:402-424

NMHPPE (1994) Netherlands ministry of housing physical planning and environment. Leidschendan Holanda

Nriagu JO, Bhattacharya P, Mukherjee AB, Bundschuh J, Zevenhoven R, Loeppert RH (2007) Arsenic in soil and groundwater: an introduction. In: Bhattacharya P, Mukherjee AB, Bundschuh J, Zevenhoven R, Loeppert RH (eds) Arsenic in soil and groundwater environment: biogeochemical. Interactions health effects and remediation. Trace metals and other contaminants in the environment vol. 9 (Series Editor Nriagu JO). Elsevier Amsterdam pp 1-58

OECD (1984) Guidelines for the testing of chemicals No. 207. Earthworm acute toxicity test. Organization for Economic Cooperation and Development Paris

OECD (2004) Guideline for the testing of chemicals No. 222. Earthworm reproduction test (Eisenia fetida/Eisenia andrei). Organization for Economic Cooperation and Development Paris

OECD (2010) Guideline for the testing of chemicals No. 317. Bioaccumulation in terrestrial oligochaetes. Organization for Economic Cooperation and Development Paris

Peijnenburg WJGM, Baerselman R, de Groot AC, Jager T, Posthuma L, van Veen RPM (1999) Relating environmental availability to bioavailability: soil-type-dependent metal accumulation in the Oligochaete Eisenia andrei. Ecotoxicol Environ Saf 44:294-310

Peijnenburg W, Sneller E, Sijm D, Lijzen J, Traas T, Verbruggen E (2002) Implementation of bioavailability in standard setting and risk assessment? J Soils Sediments 2:169-173 
Romero-Freire A, Sierra-Aragón M, Ortiz-Bernad I, Martín-Peinado FJ (2014) Toxicity of arsenic in relation to soil properties: implications to regulatory purposes. J Soils Sediments 14:968-979

Romero-Freire A, Martín Peinado FJ, van Gestel CAM (2015) Effect of soil properties on the toxicity of $\mathrm{Pb}$ : Assessment of the appropriateness of guideline values. Haz Mat 289:46-53

Saint-Denis M, Narbonne JF, Arnaud C, Ribera D (2001) Biochemical responses of the earthworm Eisenia fetida andrei exposed to contaminated artificial soil: effects of lead acetate. Soil Biol Biochem 33:395-404

Sauvé S, Hendershot W, Allen HE (2000) Solid-solution partitioning of metals in contaminated soils: dependence on $\mathrm{pH}$, total metal burden, and organic matter. Environ Sci Technol 34(7):1125-1131

Schwertmann U, Taylor RM (1977) Iron oxides. In: Minerals in soils environments Dixon J.B. Webb S.B. (Eds.). Soil Science Society of America Madison: 148-180

Sheppard SC, Evenden WG (1988) The assumption of linearity in soil and plant concentration ratios: an experimental evaluation. $\mathrm{J}$ Environ Radioact 7:221-247

Simón M, García I (1999) Physico-chemical properties of the soilsaturation extracts: estimation from electrical conductivity. Geoderma 90:99-109

Simon M, Diez M, González V, García I, Martín F, de Haro S (2010) Use of liming in the remediation of soils polluted by sulphide oxidation: a leaching-column study. J Hazard Mater 180:241-246

Smith BA, Greenberg B, Stephenson GL (2012) Bioavailability of copper and zinc in mining soils. Arch Environ Contam Toxicol 62:1-12

Smolders E, Oorts K, van Sprang P, Schoeters I, Janssen CR, McGrath SP, McLaughlin MJ (2009) Toxicity of trace metals in soil as affected by soil type and aging after contamination: using calibrated bioavailability models to set ecological soil standards. Environ Toxicol Chem 28:1633-1642
Song J, Zhao FJ, McGrath SP, Luo YM (2006) Influence of soil properties and aging on arsenic phytotoxicity. Environ Toxicol Chem 25: $1663-1670$

Spurgeon DJ, Hopkin SP (1996) Effects of metal-contaminated soils on the growth sexual development and early cocoon production of the earthworm Eisenia fetida with particular reference to zinc. Ecotoxicol Environ Saf 35:86-95

Tang X-Y, Zhu Y-G, Cui Y-S, Cuan J, Tang L (2006) The effect of ageing on the bioaccessibility and fractionation of cadmium in some typical soils of China. Environ Int 32:682-689

US NIST Certificated of Analysis Standard Reference Material ${ }^{\circledR} 2711$ (2003) Montana Soil Moderately Elevated Trace Element Concentrations Gaithersburg MD 20899

Van Gestel CAM, Hoogerwerf G (2001) Influence of soil $\mathrm{pH}$ on the toxicity of aluminium for Eisenia andrei (Oligochaeta: Lumbricidae) in an artificial soil substrate. Pedobiologia 45:385395

Van Gestel CAM, Dirven-Van Breemen EM, Baerselman R (1992) Influence of environmental conditions on the growth and reproduction of the earthworm Eisenia andrei in an artificial soil substrate. Pedobiologia 36:109-120

Van Gestel CAM, Borgman E, Verweij RA, Diez Ortiz M (2011) The influence of soil properties on the toxicity of molybdenum to three species of soil invertebrates. Ecotoxicol Environ Saf 74:1-9

Van Gestel CAM, McGrath SP, Smolders E, Diez Ortiz M, Borgman E, Verweij RA, Buekers J, Oorts K (2012) Effect of long-term equilibration on the toxicity of molybdenum to soil organisms. Environ Pollut 162:1-7

Williams L, Schoof RA, Yager JW, Goodrich-Mahoney JW (2006) Arsenic bioaccumulation in freshwater fishes. Human Ecol Risk Asses: Int J 12:904-923

Yang JK, Barnett MO, Jardine PM, Basta NT, Casteel SW (2002) Adsorption sequestration and bioaccessibility of As (V) in soils. Environ Sci Technol 36:4562-4569 